\title{
Sediment sourcing in the Gangetic alluvium, Himalayan Foreland Basin - competition between Himalayan and cratonic hinterland
}

\author{
R Sinha ${ }^{1^{*}}$, Y Kettanah², MR Gibling ${ }^{2}$, SK Tandon ${ }^{3}$, M Jain ${ }^{4}$, PS Bhattacharjee ${ }^{1}$, \\ AS Dasgupta ${ }^{1}$ and $P$ Ghazanfari ${ }^{5}$
}

\author{
1 Engineering Geosciences Group, Indian Institute of Technology, Kanpur 208016, Uttar Pradesh, INDIA \\ 2 Department of Earth Sciences, Dalhousie University, Halifax, Nova Scotia B3H 3J5, CANADA \\ 3 Department of Geology, University of Delhi, Delhi 110007, INDIA \\ ${ }^{4}$ Risø National Laboratory, Radiation Research Department, P.O. Box 49, DK-4000 Roskilde, DENMARK \\ 5 Geology Department, Natural Sciences Faculty, Tabriz University, Tabriz, IRAN \\ * For correspondence, email: rsinha@iitk.ac.in
}

The Ganga plains in the Himalayan foreland basin have been built by sediments derived from the Himalayan orogen to its north as well as from the cratons to its south. The size of the Himalayan hinterland that receives high precipitation and from where large, sediment-charged rivers originate give the impression that the cratonic rivers have contributed little to the basin compared with Himalayan drainages. However, the Betwa, Chambal and other rivers, which drain northward into the Yamuna, are vigorous monsoonal rivers with large catchments and have contributed significantly to the basin fill during the Quaternary. Our research is based on three cliff sections, seven sediment cores and modern river sand samples in the Ganga-YamunaBetwa interfluve region between Kanpur and Kotra in Uttar Pradesh, with an age model from 35 calibrated radiocarbon dates, OSL dates on quartz and feldspar, and TL dates. We have also used published water well data to map the extent of the cratonic sand wedges in the subsurface. A variety of petrographic methods have been used, viz. framework grain and dense mineral analysis, mica counts, and claymineral proportions. Unlike some geochemical methods, these petrographic methods do not allow precise modeling of Himalayan and cratonic contributions to sand and clay samples or sample groups, nor do they allow any source to be ruled out completely. However, our approach explores directly the links between the mineralogy of sediments and their potential source areas and, taking into account multiple criteria, allows a qualitative source-area assessment.

Some of the key questions investigated in this research are: (a) Can modern cratonic (Betwa and Chambal) and Himalayan (Ganga) river sands be distinguished on petrographic criteria? (b) Does older Quaternary alluvium below the Ganga Valley (Ganga Gray) resemble modern Ganga sediment? (c) Does older Quaternary red sand (Yamuna Red) resemble modern Betwa sand derived from the craton? (d) Does older Quaternary gray sediment south of the Ganga (Yamuna Gray, Chambal Gray, Sengar Gray, Rind Gray) resemble sand from any of the modern rivers? (e) During the past $\sim 120 \mathrm{ka}$, how far north did cratonic sediment reach onto the Ganga Plains, and how far south did Himalayan sediment reach?

Stratigraphic and petrographic evidences show that subsurface bodies of cratonic sediment derived largely from these rivers extend north of the axial Yamuna River. Red feldspathic sand and gravel underlies much of the southern foreland basin at shallow depth $(>30 \mathrm{~m})$, where it is dated at $119.2 \pm 12 \mathrm{ka}$ B.P., and extends at deeper levels $(>500 \mathrm{~m}$ ) to about one-third of the distance across the foreland basin. Dense mineral analysis confirms a match with modern Betwa River sands, which derive their feldspar from granitic gneisses of the Bundelkhand Complex.
Along the Yamuna Valley, gray alluvium dated at 82 to $35 \mathrm{ka} \mathrm{B.P.}$ yields a cratonic signature, with large amounts of smectite derived from the Deccan Traps, and cratonic contributions can be detected in alluvium as young as $9 \mathrm{ka}$ B.P. in a section $\sim 25 \mathrm{~km}$ north of the Yamuna. The gray cratonic sands were probably deposited in part by the Chambal River, which transports high-grade metamorphic minerals from the Banded Gneiss Complex of the Aravalli belt. Cratonic sediment appears to interfinger with Himalayan detritus at shallow depth below the Ganga - Yamuna Interfluve.

Archeological evidence suggests that the Yamuna River may have avulsed into its present position about 4,000 years ago, having previously flowed west of the Delhi-Hardwar Ridge. If so, much of the southwestern basin margin may have lacked an axial river system connected to the Himalaya prior to that time, and axial drainage would have been provided by cratonic rivers. The penetration of Himalayan sediment to the distal foreland basin may owe as much to avulsion along the fault-bounded ridge as it does to dynamic transverse drainage systems from the Himalaya pushing the axial drainage to the feather-edge of the basin. The wide spread of cratonic sediment would have been enhanced by slow subsidence in the distal foreland basin, focusing of rivers into a basin re-entrant, and the modest stream power of opposing Himalayan rivers in the western part of the basin.

We conclude that the dynamic cratonic rivers have been undervalued as contributors to the Himalayan Foreland Basin. They appear to have competed actively with the Himalayan systems in the southwestern part of the basin, where they are opposed to less vigorous rivers than those of the eastern plains (Gandak, Baghmati, and Kosi) and where the low subsidence rate enhances the areal extent of sediment wedges. It has been suggested before that dynamic transverse drainages from the Himalaya pushed the axial rivers to the feather-edge of the basin. However, the penetration of Himalayan rivers and sediment to the southwestern foreland basin may also reflect opportunistic avulsion along the fault-bounded Delhi-Hardwar Ridge. Prior to Yamuna avulsion, cratonic rivers may have contributed a considerable amount of sediment to the Ganga River and Bay of Bengal. Although the Himalaya undoubtedly provided the great bulk of sediment to these systems, more detailed geochemical characterization of northern cratonic source areas and sediment is needed in order to evaluate the cratonic contribution reliably. There may also be overlap between geochemical signatures from orogenic and cratonic sources, precluding an easy finger-printing of sediment from the two areas. 